\title{
INNOVATIVE TECHNOLOGIES IN MODERN HIGHER EDUCATION: EUROPEAN EXPERIENCE AND UKRAINIAN CONTEXT
}

\author{
TECNOLOGIAS INOVADORAS NA EDUCAÇÃO SUPERIOR MODERNA: \\ EXPERIÊNCIA EUROPEIA E CONTEXTO UCRANIANO
}

\author{
TECNOLOGÍAS INNOVADORAS EN LA EDUCACIÓN SUPERIOR MODERNA: \\ EXPERIENCIA EUROPEA Y CONTEXTO UCRANIANO
}

\author{
Mykhailo POPLAVSKYI ${ }^{1}$
}

\begin{abstract}
This study examines the issues of implementing innovative technological solutions in modern higher education, considering the accumulated European experience and in the modern Ukrainian context. The relevance of this study is conditioned by the wide spread of innovative technological solutions in the European higher education system in general and Ukraine in particular, as well as the need for a deep and comprehensive study of this process considering the prospects for the technological development of modern higher education and accumulated European experience in this field. The purpose of this study is to determine the fundamental factors that influence the development of technological innovations in the modern higher education system. The main results of this study should be the definition of the essence of innovative technologies in the modern system of higher education, the types and categories of modern innovations, as well as the main trends in academic research in this field.
\end{abstract}

KEYWORDS: Educational process. Higher educational institutions. Innovation. Pedagogical support. Modernization.

RESUMO: Este estudo examina as questões de implementação de soluções tecnológicas inovadoras no ensino superior moderno, considerando a experiência europeia acumulada e no contexto ucraniano moderno. A relevância deste estudo está condicionada pela ampla difusão de soluções tecnológicas inovadoras no sistema de ensino superior europeu em geral e na Ucrânia em particular, bem como pela necessidade de um estudo aprofundado $e$ abrangente deste processo tendo em conta as perspectivas de desenvolvimento tecnológico do ensino superior moderno e experiência europeia acumulada neste domínio. $O$ objetivo deste estudo é determinar os fatores fundamentais que influenciam o desenvolvimento de inovações tecnológicas no sistema de ensino superior moderno. Os principais resultados deste estudo devem ser a definição da essência das tecnologias inovadoras no sistema moderno de ensino superior, os tipos e categorias de inovações modernas, bem como as principais tendências da pesquisa acadêmica neste campo.

PALAVRAS-CHAVE: Processo educacional. Instituições de ensino superior. Inovação. Suporte pedagógico. Modernização.

${ }^{1}$ Kyiv National University of Culture and Arts (KNUCA), Kyiv - Ukraine. Professor. Doctor of Pedagogical Sciences. ORCID: https://orcid.org/0000-0002-8234-8064. E-mail: m.poplavskyi@tanu.pro

RPGE- Revista on line de Política e Gestão Educacional, Araraquara, v. 25, n. esp. 3, p. 1698-1711, Sep. 2021. e-ISSN: 1519-9029 DOI: https://doi.org/10.22633/rpge.v25iesp.3.15586 
RESUMEN: Este estudio examina los problemas de la implementación de soluciones tecnológicas innovadoras en la educación superior moderna, considerando la experiencia europea acumulada y en el contexto ucraniano moderno. La relevancia de este estudio está condicionada por la amplia difusión de soluciones tecnológicas innovadoras en el sistema de educación superior europeo en general y Ucrania en particular, así como la necesidad de un estudio profundo y completo de este proceso considerando las perspectivas de desarrollo tecnológico de educación superior moderna y experiencia europea acumulada en este campo. El propósito de este estudio es determinar los factores fundamentales que influyen en el desarrollo de las innovaciones tecnológicas en el sistema de educación superior moderno.. Los principales resultados de este estudio deben ser la definición de la esencia de las tecnologías innovadoras en el sistema moderno de educación superior, los tipos y categorías de innovaciones modernas, así como las principales tendencias en la investigación académica en este campo.

PALABRAS CLAVE: Proceso educativo. Instituciones de educación superior. Innovación. Apoyo pedagógico. Modernización.

\section{Introduction}

Nowadays, there is a large-scale implementation of innovative technological solutions in institutions related to the system of modern higher education. Currently, the development of Ukraine should be defined within the framework of European integration with a focus on fundamental values and education at any level, which should be considered a mandatory attribute of a civil democratic society. The transformation of the principles of spiritual development of Ukrainian society is the crucial aspect of solving a number of tasks defined by the strategy of its renewal, national revival and European integration. This strategy determined not only by the problems of the state structure of Ukraine, but also by the fundamental changes in the culture of humanity at the turn of the millennium, which provided for the innovative potential of the post-industrial society. One of the factors influencing the dynamics of this process is high school, whose status and functionality are constantly changing (WARTMAN, 2015; WATTED; BARAK, 2018).

Nowadays, the strategy of improving the quality of education involves the mutual enrichment of traditions and values in the modern world, while preserving local ones. Education and upbringing are constantly changing, and this fact should be considered as a reaction to a new social demand. The defining aspect of the entire development is innovation (MILLER, 2000; OOSTHOEK, 2013). Nowadays, innovative technological solutions are the determining factor that impact the processes of developing progressive thinking among students of modern higher educational institutions (HEI) significantly, developing their ability to observe the changing conditions of the external world and adapt to them quickly. The 
structural transformations in the modern world, deriving from economic and cultural globalisation, requires modernization of the education sector as one of the main social institutions. In the modern world, where information and knowledge are a strategic commodity, and human resources are the main national wealth, the importance of the educational function in everyday life is growing significantly. The education system is one of the primary tools for establishing cultural, economic, and political stances of the state on a global scale. Consequently, the modernization of education should be a strategic task for the current society (ROVAI, 2009; CROOK; SCHOFIELD, 2017).

The prevalence of high-tech industries in the economic traditions significantly changes the requirements for training of the personnel, their professional and creative features. The strategy for modernization of the Ukrainian higher school is focused on the development of strategic competencies in the intellectual, socio-political, communication, and information fields. This task has become particularly relevant in the post-Soviet space since the strategy for developing the educational process in the modern world has changed significantly in recent years. While previously information was updated every 20-30 years, it is updated by $20 \%$ per year at the moment, that is, it is updated completely every five years, and in certain scientific fields even faster. Due to the rapidly changing information, the large-scale use of innovative learning technologies in many countries, the higher education system is being reformed by focusing on continuity, diversification, comprehensiveness, humanization, democratization and integration into a single educational space (BENSON; BRACK, 2010; XIE et al., 2018; VIGENTINI et al., 2020).

The ability of higher education to quickly adapt to extended knowledge to maintain the quality of education is crucial, and the sensitivity of the higher education system to current innovative changes is essential. The innovative potential of higher education is determined primarily by the level of development of the organization of its internal social space, as well as the innovation environment. The development of innovative training technologies should be considered as an essential component in ensuring competitive higher education. The educational process is based on technology transfer, which is the movement of technology using certain channels of information transfer from its individual or collective data medium to another one (GLAVAS; SCHUSTER, 2020; CHEN et al., 2018).

The leading method in this research is a combination of a systematic analysis of the features of the development and implementation of innovative technological solutions into the system of modern higher education, along with an analytical study of the accumulated European and Ukrainian experience in the development of modern innovative technologies in 
institutions of higher education in Europe and in Ukraine within the framework of identifying the features of the impact of innovative technological solutions on the functioning of institutions of modern higher education.

The purpose of this research is to determine the fundamental factors that influence the development of technological innovations in the modern higher education system, as well as the prospects for their extensive use in modern higher education institutions in Europe and Ukraine. Thus, the role of innovative technologies in the system of modern higher education is crucial and requires a deep and qualitative study, considering the accumulated European experience in modern Ukraine.

\section{Literature review}

A review of the literature sources, which subject matter is the role of information technologies in modern higher education considering the accumulated European experience in modern Ukraine, indicates a significant interest of scholars in these issues. Thus, in the study of the mechanisms of state regulation of the system of modern higher education, V. P. Sadkovoy (2014) notes that modern higher education is attracting attention of state management science, sociologists, political scientists, cultural studies scientists, psychologists and philosophers who seek to combine efforts for expert forecasting of the ways of its development and predicting the risks accompanying this process. Ukrainian society, which is going through a complicated stage of development full with all sorts of transformations, emphasize the problems that are part of the subject field of innovation processes, and determine the range of issues related to the definition of another subject field, which is the key aspects of the knowledge society.

At the same time, Ye. N. Sulima (2018), when assessing the prospects for the implementation and development of innovations in the system of Ukrainian higher pedagogical education, emphasizes that the evaluation of key studies and publications in the Ukrainian pedagogical literature proves the relevance of the topic related to innovations in teachers' education. The author notes that a lot of new ideas are focused on the issues of developing an assessment of the quality of education, creating a special responsibility for teachers for positive changes in education, eliminating contradictions between the pace of sociocultural development of pupils and the tasks of the current society, achieving equal opportunities in receiving quality education. At the same time, Yu. S. Bortsov and A. M. Starygina (2015) note that within the framework of the sociological discussion the volume of 
academic research dedicated to the development of a strategy for the modernization of modern higher education and the use of innovative models and technologies in the organization of the educational process is growing.

According to V. N. Vernyakhovskaya (2019), innovations in the field of modern higher education include special educational technologies, individual experimentation, innovative curricula, reforms that determine changes in the number of students, the order of obtaining education and its funding, new learning strategies. Notably, in another study, the author emphasizes that educational innovations are expressed in the implementation of synergetic connections and can be associated with both the improvement of learning technologies and the transformation of the educational product itself. The concept of "technology" includes all the knowledge and experience that can be effectively used in the development of scientific, entrepreneurial and other projects (VERNYAKHOVSKAYA, 2012). Thus, scholars define the importance of these issues and the need for their deep and comprehensive study, considering the modern higher education system.

\section{Methodology}

This research studies the features of the application of innovative technologies in modern higher education, considering the accumulated European experience and situation in modern Ukraine. The subject matter of this research is innovation activity as a scientific problem for the application of innovative technologies in the modern educational process, considering modern system of higher education. The leading method in this research is a combination of a systematic analysis of the features of the development and implementation of innovative technological solutions into the system of modern higher education, along with an analytical study of the accumulated European and Ukrainian experience in the development of modern innovative technologies in institutions of higher education in Europe and in Ukraine within the framework of identifying the features of the impact of innovative technological solutions on the functioning of institutions of modern higher education.

Nowadays, technological innovations have a significant impact on the modern institutions of higher education due to the widespread implementation of innovative technologies in the higher educational institutions, when designing the educational process and developing the necessary professional competencies among modern students. The systemic analysis of the features of the development and implementation of innovative technological solutions in the system of modern higher education performs the function of 
identifying objectively the main trends in the innovative development of the modern system of higher education in terms of the essence, categories and main relevant fields of research of modern innovative technologies of the education system. At the same time, an analytical study of the accumulated European and Ukrainian experience in the development of modern innovative technologies can provide an objective answer to questions concerning the use of information and communication technologies in the study of disciplines, the use of personality-oriented technologies in the educational process of higher educational institutions in specific academic disciplines, information and analytical support for the educational process, as well as the need and feasibility of developing and implementing the principles of psychological and pedagogical support for the implementation of innovative technologies in the educational process.

Thus, the choice of the methodology for this research serves to provide the most complete and objective description of the issues submitted for consideration in terms of a qualitative assessment of the degree of introduction of innovative technologies in the modern higher educational institutions and their impact on the development of professional competencies among students of modern universities. The materials of this research are information taken from the works of foreign scholars who studied the role and significance of innovative technologies in the system of modern higher education when assessing the existing European experience and situation in modern Ukraine. To facilitate the comprehension of the information provided and to create the most objective picture of the academic research, all the materials taken for study from the sources by foreign authors and presented in this study have been translated into English. In general, the combination of materials and methods chosen as the foundation for the methodology of this research can be considered optimal in terms of compliance with the tasks set and can be effectively used for further study in this field.

\section{Results}

The study of various aspects of innovative technologies in the system of modern higher education, considering the accumulated European experience and situation in modern Ukraine, gave the following results. Innovation activity as an educational problem attracts the attention of scholars engaged in academic developments in the field of improving the technological base of the educational process in the system of modern higher education. In general, the differences between conventional and innovative systems of higher education are primarily in the goal settings performed through various educational technologies. The 
European experience of implementing innovative technologies in the higher education system emphasizes the urgent need for a higher education institution to produce a specialist who can already take an active part in the development of the latest technological solutions, successfully adapt to the conditions of a specific production environment, and act as an effective medium of innovative technological solutions.

First of all, innovation activity as a research problem implies the need to develop and implement effective mechanisms for assessing the importance of innovative technologies in the system of modern higher education from scientific novelty perspective and prospects for influencing establishment scientific development of the modern system of higher education. Here, it is important to evaluate innovative technologies in modern higher education in terms of their essence, categories and research trends. Figure 1 shows the categories of innovative technologies used in the current higher education system.

Figure 1 - Categories of Innovative Technologies Currently Used in the Higher Education System

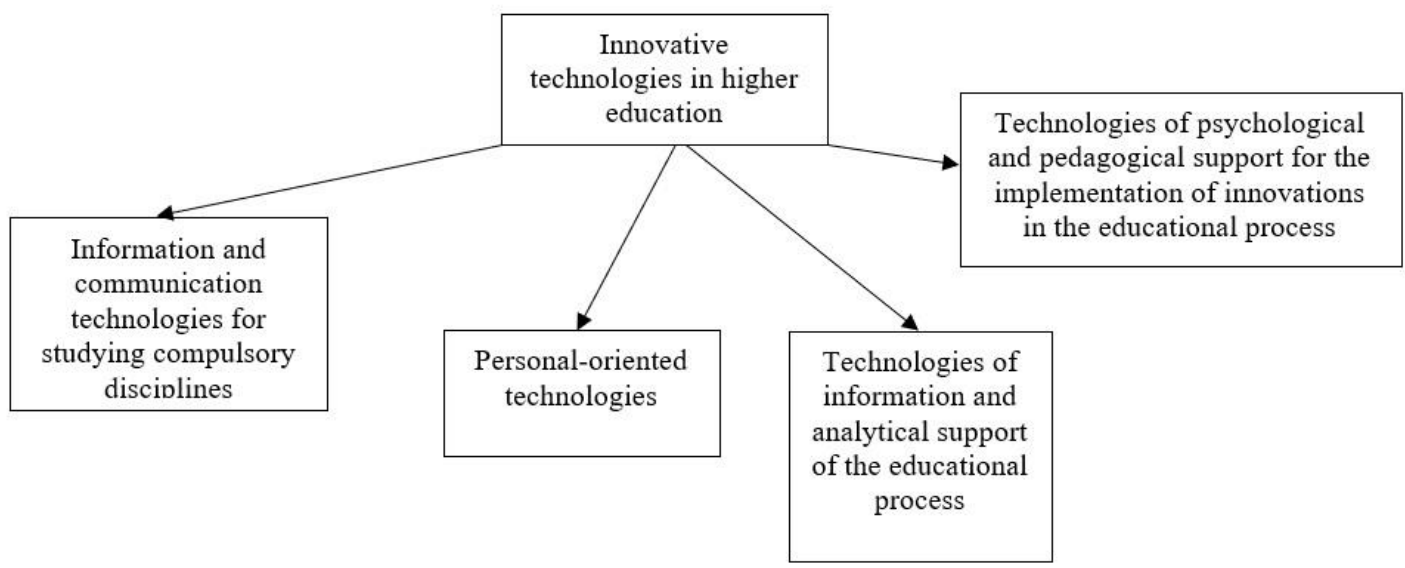

Source: Prepared by the authors

The essence of innovative educational technologies is to create favorable conditions for improving the quality of students' understanding of information and its subsequent comprehension considering trends in the modern system of higher education. Modern trends in the research of the essence of innovative technologies in higher education reveal the consistent development and complication of the information systems and technologies, which significantly affects the system of university education and training of future specialists who can solve the tasks qualitatively. Specialists trained in the modern higher education system must not only meet the latest requirements in the various fields of social activity but also to be ready to make progress in all these areas. In modern higher education, innovative technologies 
of various types are used, which can provide a qualitative solution to the issues of improving the existing system of higher education and the quality of training of future specialists.

1. Information and communication technologies in higher education. The relevance of the implementation of information and communication technologies in the system of modern higher education, considering situation in modern Ukraine, is determined by a number of objective factors. First of all, modern higher professional education in Ukraine is focused on training specialists capable of successful professional activity, considered massive volumes of information in modern society. In this case, information and communication technologies are a mastered area of professional knowledge. At the same time, information and communication technologies in modern higher education can support almost all types of activities of higher education institutions such as organization, management and tracking of trends in the educational process; automated training and its data and methodological support; providing access to standard information resources; providing modern information processing technologies; remote interaction of participants in the educational process. In this case, information and communication technologies should be considered as typical educational technologies that require an information culture among the teaching staff and students. Figure 2 shows the frequency of using various types of information and communication technologies in the educational process of higher education institutions.

Figure 2 - Frequency of using various types of information and communication technologies in the educational process of higher education institutions

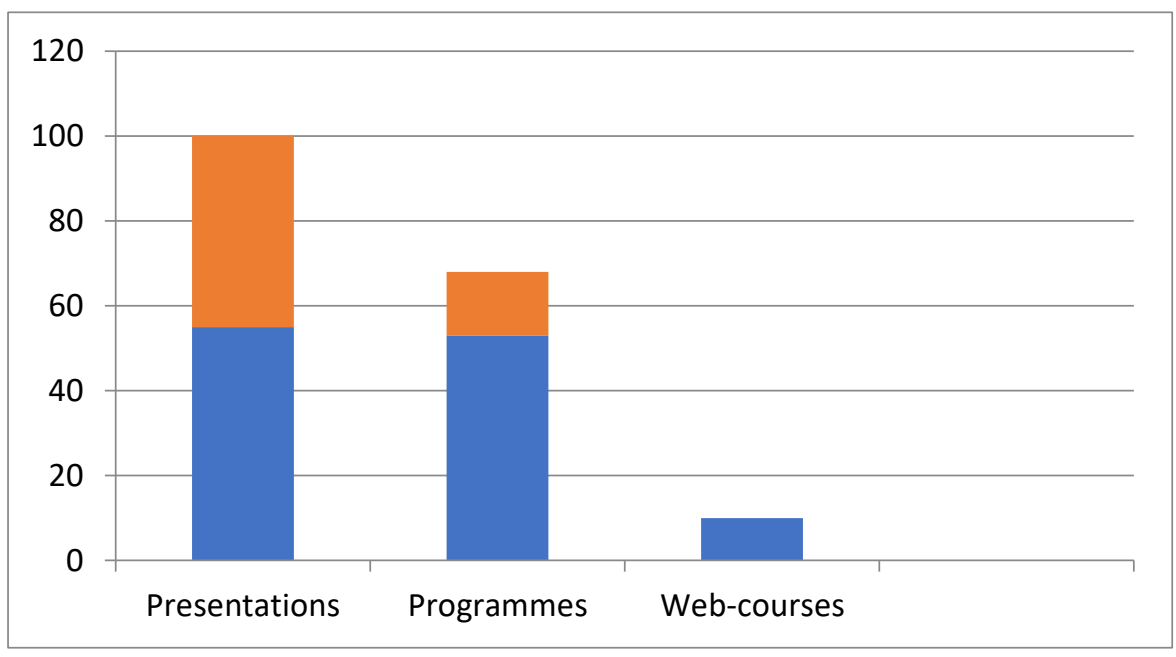

Source: Prepared by the authors

According to the data in Figure 2, presentation is the most common form of information and communication technologies in the educational process, it is used by $55 \%$ of 
university teachers constantly and 45\% when needed. The corresponding statistics for specialized programs are $53 \%$ and $15 \%$, for web courses $10 \%$. This can be explained by the fact that the technology of creating a presentation is the most developed and accessible technology for conducting the educational process.

2. Personality-oriented innovative technologies in the teaching of compulsory disciplines. Personality-oriented innovative technologies in the teaching of compulsory disciplines in the higher education system imply the development of practical training programs that consider the personal traits of individual students. The concept of innovation, when applied to university education, represents certain changes within the education system. Personality-oriented technologies of teaching compulsory disciplines suppose that innovations can qualitatively improve the educational process.

3. Information and analytical support of the educational process. This type of Innovative technologies effectively solves the problems of providing the educational process in higher education with information and modern methods of analysis necessary for the timely and high-quality solution of the tasks set for the teaching staff. Information is the main link between the concepts of "organization", "management" and "administration" as applied to the educational process in the university. Any type of educational process management can be considered as a process of information transfer followed by its analysis.

4. Psychological and pedagogical support for the implementation of innovative technologies in the educational process. Pedagogical innovations can turn potential concepts and ideas into real changes in the educational process, focused on developing students' skills of independent work, critical analysis and unconventional thinking. Psychological and pedagogical support of innovative technologies in the educational process contributes to the implementation of the latest pedagogical models, the development of executive and managerial structures, the implementation of innovative methodological products into the educational process, including pedagogical program materials. Innovative technologies should be considered as a combination of the latest pedagogical developments that can qualitatively improve the course of the educational process and the style of teaching particular disciplines.

In general, innovative technologies in modern higher education, considering European experience and situation in modern Ukraine, can effectively solve the problems of modernization of the educational process to achieve maximum correspondence to the requirements of the modern labor market, from the standpoint of the development of university graduates professional competencies necessary for the qualitative satisfaction of the needs of this market in general and modern employers in particular.

RPGE- Revista on line de Política e Gestão Educacional, Araraquara, v. 25, n. esp. 3, p. 1698-1711, Sep. 2021. e-ISSN: 1519-9029 DOI: https://doi.org/10.22633/rpge.v25iesp.3.15586 


\section{Discussion}

The discussion of the development and practical use of innovative technologies in the system of modern higher education, considering European experience and situation in modern Ukraine, allows for comparing the results of this research with the conclusions of scholars who conducted studies in this field. When considering application of European experience in the situation of modern Ukraine, V. P. Sadkovoy (2014) notes that over the past few years there has been a gradual social understanding of the requirements that the involvement of Ukraine in the general European Bologna process has set for the educational environment. One of the main problems is the closing the gap between both university curricula and the system of their teaching and the existing trends in the labor market. Historical experience shows that the content and model approaches in education policy are always dependent on the general trends of socio-economic, scientific and cultural development of the world.

At the same time, in the study of innovative processes in Ukrainian higher pedagogical education, Ye. N. Sulima (2018) emphasizes that the concept of "innovation" is identified by Ukrainian scholars as the one equal to the processes of improvement, renewal, restructuring, optimization, modernization, transformation, diversification, orientation towards new trends. There are specific changes and innovations, which in practice gives new improved results. Considering this, innovation has a multi-vector significance since in addition to defining a new idea it involves the process of its realization, which is described by changes in the principles of activity, life, and way of thinking; it has a strong connection with the transition to a fundamentally new state through the revision of outdated norms, positions, views, roles, etc. In her scientific study of the features of modern higher education as a key component of the national innovation system (NIS), V. N. Vernyakhovskaya (2019) notes that universities should become an integral part of the NIS, which determines the need for a transformation of their main functions both for the field of professional training and for the organization of academic research. In particular, the integration of higher education institutions into the NIS involves the modification of the content and main objectives of training, considering the needs of the economy, as well as the strengthening of the role of educational institutions in performing academic research activities and using the results obtained during this process for the economy.

Foreign authors did not ignore the number of issues raised. In particular, P. Rambe and S. Mlambo (2014) note that the qualitative organization of implementation of innovative technologies in the system of modern higher education will create an effective system that can 
solve the issues of qualitative development of innovative potential, advancement of the research results and development work in the real economy sector. According to A. Mavri, A. Loannou, F. Loizides (2021), improving the forms of technology transfer will significantly increase the efficiency of implementing innovations in higher education, shorten the path of research from its creator to the consumer. European universities are actively moving in this direction, steadily increasing the number of new organizational structures to support technology transfer.

In their turn, M. A. Song and S. C. Kong (2017) note that the focus of modern education on personality-oriented pedagogy requires activating the potential of all participants of the pedagogical process. A variable approach to the education process is necessary to solve this problem. Nowadays, innovations are common for any professional activity, and, therefore, it is quite natural that they are actively studied, analyzed and implemented. However, the implementation of innovations cannot occur spontaneously, this process must be controlled. Thus, modern scholars' ideas about the role of innovative technologies in modern higher education considering the European experience and situation in modern Ukraine largely coincide with the results of this study, despite the fact that scholars have their reasonable stances regarding a number of issues that relate to the research topic of this study.

\section{Conclusion}

The study of various aspects of innovative technologies in the system of modern higher education, considering the accumulated European experience and situation in modern Ukraine, gave the following results. Innovative technologies play a crucial role in the system of modern higher education, acting as one of the main driving factors of its development. The use of innovative technological solutions in the higher education system of Ukraine allows for reaching a new qualitative level of the solution of a number of issues, including increasing the level of clarity of educational material, clarity of explanation of the main theses of the educational process, which generally has a positive effect on the level of understanding of the information provided to university students, and, consequently, the better development of their future professional competencies.

In addition, innovative technologies in the higher education system of Ukraine implemented by considering the accumulated European experience are a tool for solving the issues of improving the communicative function of the educational process of a modern university and, simultaneously, effectively solving the problems of personal orientation of 
students in the development of professional competencies, as well as the implementation of advanced educational technologies in higher education system in modern Ukraine. At the same time, the introduction of the latest innovations in higher education requires appropriate preliminary training of both teaching staff and students within the framework of development of their competencies necessary for the qualitative development of the features of innovative technologies in terms of their understanding and proper use to obtain practical results. In general, the successful application of modern innovative technologies in higher education considering the accumulated European experience and situation in modern Ukraine allows for providing a new additional impetus to the development of the higher education system and create a qualitative foundation for the improvement of education standards in general, considering the opportunities for the development of professional competencies of students through the implementation of the latest innovations in the higher education system.

\section{REFERENCES}

BENSON, R., BRACK, C. Online learning and assessment in higher education. Colchester: Chandos Publishing, 2010.

BORTSOV, YU.S.; STARYGINA, A.M. The strategy of innovative development of higher education in Russian Federation: opportunities and constraints, 2015. Available in: https://cyberleninka.ru/article/n/strategiya-innovatsionnogo-razvitiya-vysshego-obrazovaniyav-rossii-vozmozhnosti-i-ogranicheniya.

CHEN, B.; CHANG, Y.-H.; OUYANG, F.; ZHOU, W. Fostering student engagement in online discussion through social learning analytics. The Internet and Higher Education, n. 37, pp. 21-30, 2018.

CROOK, C.; SCHOFIELD, L. The video lecture. The Internet and Higher Education, n. 34, pp. 56-64, 2017.

GLAVAS, C.; SCHUSTER, L. Design principles for electronic work integrated learning (eWIL). The Internet and Higher Education, n. 47, Article number: 100760, 2020.

MAVRI, A.; LOANNOU, A.; LOIZIDES, F. Cross-organisational Communities of Practice: enhancing creativity and epistemic cognition in higher education. The Internet and Higher Education, n. 49, Article number: 100792, 2021.

MILLER, I. Distance learning - a personal history. The Internet and Higher Education, v. 3, n. 1-2, pp. 7-21, 2000.

OOSTHOEK, H. Higher education and new technologies. Oxford: Pergamon Press, 2013. 
RAMBE, P.; MLAMBO, S. Using digital storytelling to externalise personal knowledge of research processes: The case of a Knowledge Audio repository. The Internet and Higher Education, n. 22, pp. 11-23, 2014.

ROVAI, A. The Internet and higher education. Colchester: Chandos Publishing, 2009.

SADKOVOY, V.P. Mechanisms of state reforming of higher professional education in Ukraine. Actual Problems of the Humanities and Natural Sciences, v. 7, n. 2, pp. 183-187, 2014.

SONG, Y.; KONG, S.C. RETRACTED: Affordances and constraints of BYOD (Bring Your Own Device) for learning and teaching in higher education: Teachers' perspectives. The Internet and Higher Education, n. 32, pp. 39-46, 2017.

SULIMA, YE.N. Innovative processes in Ukrainian higher pedagogical education. Domestic and Foreign Pedagogy, n. 2(48), pp. 82-91, 2018.

VERNYAKHOVSKAYA, V.N. Promising forms of technology transfer in higher education. Science and Innovation, n. 6(112), pp. 47-50, 2012.

VERNYAKHOVSKAYA, V.N. Higher education as a key component of the national innovation system. Science and Innovation, n. 5(195), pp. 45-49, 2019.

VIGENTINI, L.; LIU, D.Y.T.; ARTHARS, N.; DOLLINGER, M. Evaluating the scaling of a LA tool through the lens of the SHEILA framework: A comparison of two cases from tinkerers to institutional adoption. The Internet and Higher Education, n. 45, Article number: 100728, 2020.

WARTMAN, S. The transformation of academic health centers. London: Academic Press, 2015.

WATTED, A.; BARAK, M. Motivating factors of MOOC completers: Comparing between university-affiliated students and general participants. The Internet and Higher Education, n. 37, pp. 11-20, 2018.

XIE, K.; DI TOSTO, G.; LU, L.; CHO, Y.S. Detecting leadership in peer-moderated online collaborative learning through text mining and social network analysis. The Internet and Higher Education, n. 38, pp. 9-17, 2018. 


\section{How to reference this article}

POPLAVSKYI, M. Innovative technologies in modern higher education: European experience and Ukrainian context. Revista on line de Política e Gestão Educacional, Araraquara, v. 25, n. esp. 3, p. 1698-1711, Sep. 2021. e-ISSN:1519-9029. DOI: https://doi.org/10.22633/rpge.v25iesp.3.15586

Submitted: $20 / 03 / 2021$

Required revisions: $05 / 06 / 2021$

Approved: $12 / 07 / 2021$

Published: 01/08/2021 